\title{
Leveraging Technology Through Crowdfunding to Ease Barriers of Entry Into the Marketplace
}

\author{
Amye Melton, DBA \\ Austin Peay State University, Clarksville, Tennessee, United States \\ (iD) https://orcid.org/0000-0002-8298-9873 \\ Terry Damron, EdD \\ Austin Peay State University, Clarksville, Tennessee, United States \\ (iD https://orcid.org/0000-0002-7999-9237 \\ Vikkie McCarthy, PhD \\ Austin Peay State University, Clarksville, Tennessee, United States \\ (iD) https://orcid.org/0000-0002-5017-7299 \\ William Rupp, $\mathrm{PhD}$ \\ Austin Peay State University, Clarksville, Tennessee, United States \\ Contact: mccarthyv@apsu.edu
}

\section{Abstract \\ Small businesses and entrepreneurs face barriers to entering new markets, such as access to capital. Crowdfunding is one method for financing new ventures. The purpose of this article is to explore how crowdfunding can ease barriers of entry into new markets. Drawing from strategic management, planning, marketing, and technology acceptance literature, we present a conceptual model to explain the use of crowdfunding by small businesses and entrepreneurs. Factors that impact individuals' propensity to utilize crowdfunding as a source of capital include ease of use, intention to use, attitudes toward use, and effectiveness.}

Keywords: strategic management; strategy; technology; marketing; barriers to entry; crowdfunding; social networking

Date Submitted: January 25, 2019 | Date Published: June 1, 2020

\section{Recommended Citation}

Melton, A., Damron, T., McCarthy, V., \& Rupp, W. (2020). Leveraging technology through crowdfunding to ease barriers of entry into the marketplace. International Journal of Applied Management and Technology, 19, 77-86. https://doi.org/10.5590/IJMAT.2020.19.1.06 


\section{Introduction}

Incorporating short- and long-term business objectives is a core activity of strategic management (Porter, 1980). However, new technology and digitization is redefining long term (Oviatt \& Miller, 1989). For many years, companies were told to develop a strategic plan and stick to the plan, making only minor tweaks along the way (Jennings \& Disney, 2006). With technology enhancements, organizations must be nimble and make strategic corrections more often (Cummings et al., 2013; Nyuur, 2015). More importantly, technology gives adept entrepreneurs a competitive advantage in dynamic markets (Saviotti \& Pyka, 2011; Spulber, 2003).

\section{Background of the Problem}

A major market barrier for entrepreneurs and small startups is the ability to raise capital (Porter, 1980; Talaia et al., 2016). Minorities, women, and entrepreneurs from less developed countries face extra challenges for raising capital to start new business ventures (Bewaji et al., 2015; Naidu \& Chand, 2017; Saviotti \& Pyka, 2011). One method of raising capital through technology is crowdfunding which is an "open invitation addressed to the public, (with) the aim to obtain financial resources for a specific project," (Wierzbicka, 2018, p. 57). Some research indicates leveraging technology through practices such as crowdfunding may ease this barrier to entry by making funding more accessible (Borello et al., 2015; Saviotti \& Pyka, 2011). Crowdfunding has also allowed new products to be introduced to the market, circumventing traditional methods such as venture capitalists (Belleflamme et al., 2013; Rossi, 2014; Wierzbicka, 2018). As traditional methods of financing are circumvented, the complexity of barriers to entry in the marketplace is also being circumvented (Spulber, 2003). There has been, however, little attempt to create a conceptual framework linking crowdfunding to market entry barriers. Jim Euchner (2015) posited crowdfunding may ease four specific barriers to entry: (a) economies of scale, (b) access to capital, (c) access to distribution, and (d) incumbency advantages (cost disadvantages independent of scale). This article attempts to merge Euchner's speculation with the technology acceptance model (TAM) to create a conceptual framework for strategically using crowdfunding as a tool to lower the access to capital thus easing this barrier to entry. The primary research question is, "What factors impact entrepreneurs' propensity to use crowdfunding in order to raise capital for new ventures?”

\section{Literature Review}

Porter (1980) outlined the five forces framework to identify degree of competition and resulting attractiveness of an industry: barriers to entry, power of suppliers, power of buyers, substitute products, and intense rivalry. The five forces framework is best when applied to for-profit industries (Oviatt \& Miller, 1989). All five forces are typically in play at one time, and it is difficult to discuss one force without mentioning all five; however, the authors will attempt to focus primarily on access to capital as a barrier to entry.

Porter (1980) identified seven main barriers to entry: economies of scale, access to capital, access to distribution, and incumbency advantages, switching costs, government policy, and network effects. Euchner (2015) argued that the digital revolution may be responsible for eroding the first four of these. To narrow the scope of the article even more, the authors will focus primarily on access to capital as an eroding barrier to entry.

Microeconomic theory states new competitors enter an industry because they believe profit can be made (Bain, 1956; Das, Roberts, \& Tybout, 2001). Furthermore, profit for new entrants can be depleted over time if new competitors continue to enter the market leading to the need to create higher barriers to entry to protect new entrants' position in the market. Depending on the industry, substantial investment of capital may or may not be necessary to enter a market. In addition to time and foregone earnings of previous employment, 
entrepreneurs may find significant expenses related to creating a business. These significant expenses are typically the first barrier to entry an entrepreneur encounters (Bruton, Khavul, Siegel, \& Wright, 2015).

\section{Economies of Scale}

Bain (1956) found entry barriers vary with industry. Klapper, Laeven, and Rajan (2006) suggested entry barriers may negate the disciplining effect of competitors in countries with high entry barriers. Bain (1956) termed two types of entry barriers: strategic and structural. Structural barriers are not created by a firm, while a strategic barrier is an intentional effort by a firm to protect its position in the industry. Structural barriers may create an environment where a new entrant without existing capital would not be able to achieve a minimum efficient scale (Lofstrom, Bates, \& Parker, 2014, p. 234).

Startups choosing a cost leadership strategy may find their potential competitors have the ability to achieve a minimum efficient scale therefore creating a high capital requirement (Lofstrom et al., 2014). Startups may choose to not enter a market due to competitors being able to decrease costs over the long run. Competitors intentionally develop a low cost strategy to raise barriers of entry.

\section{Access to Capital}

Capital requirements were once thought of as one of the biggest hurdles for an entrepreneur (Dahlqvist, Davidson \& Wiklind, 2000; Voelker \& McGlashan, 2013). Entry is eased when bank and trade credit are available (Klapper et al., 2006). Deloitte Touche Tohmatsu Limited estimated more than $\$ 3$ billion was raised through crowdfunding in 2013 (Sholeh \& Mackey, 2015). Access to capital comes in one of three ways: (a) borrowing, (b) trade credit, and (c) personal wealth (Disney \& Gathergood, 2009; Fairlie \& Krashinsky, 2012; Klapper et al, 2006). Entrepreneurs with personal wealth enter high-barrier industries more easily (Lofstrom et al., 2014).

\section{Access to Distribution and Incumbency Advantages}

Existing competitors have experience and relationships that startups do not. In addition, competitors may have already established preferred access to raw materials. The incumbent is a known organization with a potentially dedicated customer. Startups must overcome customer loyalty and the experience of their competition (Dahlqvist et al., 2000). This barrier to market entry can be overcome with large sums of available money if a small business or entrepreneur can overcome the access to capital.

\section{Crowdfunding}

Crowdfunding, or crowdsourced fundraising, is an extension of the broader concept of crowdsourcing (Poetz \& Schreier 2012; Thurlow \& Yue 2012; Yeoh, 2014). Whereas crowdsourcing involves using a network of individuals to develop creative solutions, crowdfunding entails using a network of individuals to develop funding (Gerber \& Hui, 2013). Using the power of the Internet and social networks, crowdfunding provides startups and small and medium enterprises (Wroldsen, 2013). The significance is that small and medium enterprises typically to struggle to obtain capital via limited traditional funding channels and typically rely on nonbanking finance (O'Toole, Lawless \& Lambert, 2015) - with an efficient, cost-effective opportunity to secure funds from countless investors around the world (Bradford, 2012; Colgren, 2014).

While terminology and definitions of types of crowdfunding vary across the literature, four types are generally discussed: donation-based, rewards-based, lending-based, and equity-based (Bouncken, Komorek, \& Kraus, 2015; Colgren, 2014; Hollas, 2013). All of these are part of a growing technology process that is disrupting the capital market space (Beaulieu, Sarker \& Sarker, 2015). 


\section{Donation-based crowdfunding projects}

These types of projects offer the investor no tangible reward in exchange for financial support and are less commonly funded than rewards-, lending-, and equity-based crowdfunding projects (Belleflamme et al., 2013). Donation-based campaigns around the world received an average of $\$ 3,363$ in 2014 (Boslet, 2015). Donating funds through sites such as GoFundMe.com and Indiegogo.com, funders support social causes, creative projects, humanitarian aid, and other efforts.

\section{Rewards-based crowdfunding is another form of crowding funding}

In exchange for financial support, those who fund rewards-based crowdfunding campaigns via platforms such as Kickstarter receive a tangible reward of some type, such as a memento of gratitude (t-shirt, decal) or first receipt of the product once ready for distribution. Rewards vary according to level of contribution in tiered campaigns. In 2014, reward-based crowdfunding grew $84 \%$ and the average campaign yielded $\$ 3,189$ (Boslet, 2015).

\section{Lending-based crowdfunding}

This a form of investment crowdfunding that is sometimes referenced as marketplace lending, peer-to-peer lending, debt-based crowdfunding, or credit-based crowdfunding. Lending-based crowdfunding campaigns allow investors to earn interest on the money they lend to the project. Lending and borrowing is completed online via platforms such as Prosper and Lending Club without the involvement of a financial institution or use of an escrow system. These types of campaigns represent the largest segment of the industry, with 2015 funding expected to total $\$ 25.1$ billion ("Global crowdfunding market," n.d.). Easily fulfilling the role of a bank and offering a more efficient opportunity for expansion, this form of crowdfunding poses the most significant threat to traditional finance (Hollas, 2013). Lending-based crowdfunding, however, is also high risk for investors due to information asymmetry, anonymity, lack of control, and potential opportunism (Chen, Lai \& Lin, 2014).

\section{Equity-based crowdfunding}

Equity-based crowdfunding is also a form of investment crowdfunding, allows investors to receive compensation in the form of shares or a percentage of sales and provides businesses that might otherwise seek-but not necessarily obtain-funding from angel investors and venture capitalists with an opportunity to gain access to necessary capital (Manchanda \& Muralidharan, 2014). Nonfinancial motives typically play little to no role in the decision to invest in these campaigns (Cholakova \& Clarysse, 2015; Cummings et al., 2013), which are made available via sites such as Crowdfunder.com, AngelList.com, and Localstake.com. The majority of businesses engaging in equity-based crowdfunding are startups (Borello et al., 2015). Equity-based crowdfunding totals were projected to reach \$2.56 billion in 2015 (“Global Crowdfunding Market,” n.d.). Compared to donation-, rewards-, and debt-based crowdfunding, funds raised via equity-based crowdfunding represent the smallest portion of the industry. The reasons for such a small representation are due to legal restrictions on how funding needs may be advertised and which consumers are allowed to invest (Yeoh, 2014).

\section{Technology Acceptance Model}

As the gap between supply and demand for entrepreneurial funding grew in the wake of the 2009 financial crisis, crowdfunding gained popularity (Bruton et al., 2015; Yeoh, 2014). Growth has continued for this alternative form of financing, with global crowdfunding totals growing from $\$ 6.1$ billion in 2013 to an expected $\$ 34.4$ billion in 2015 ("Global Crowdfunding Market," n.d.). One reason for the significant growth in crowdfunding was the change in Title II of the U.S. Jumpstart Our Business Startups Act. This change went into effect in September 2013. It removed "the ban on general solicitation, allowing startups to raise funds through new social media networks, (“TABB Says," 2014).

The rapid rate of adoption among both campaign creators and funders can also be explained in part by the TAM, which is a model commonly used to predict and explain user adoption or rejection of computer-based 
technology and information systems (Davis et al., 1989; Ma \& Liu, 2004; Yousafzai et al., 2010). An extension of the theory of reasoned action, the TAM identifies two determinants of intended behaviors: attitudes and subjective norms (Davis, 1986). According to TAM, user acceptance is determined by the user's perceptions of a technology's ease of use (perceptions that using the system will require no effort) and usefulness (perceptions that using the system will enhance job performance; Davis, 1989).

\section{Findings}

The use of crowdfunding by entrepreneurs and small startups is dependent upon two factors, effectiveness of crowdfunding and individual attitudes related to crowdfunding (Lacan \& Desmet, 2017). The latter variable, attitudes, is a latent variable that may be measured through two observable variables, perceived ease of use, and intention to use. Figure 1 illustrates the relationships between these latent and observed variables.

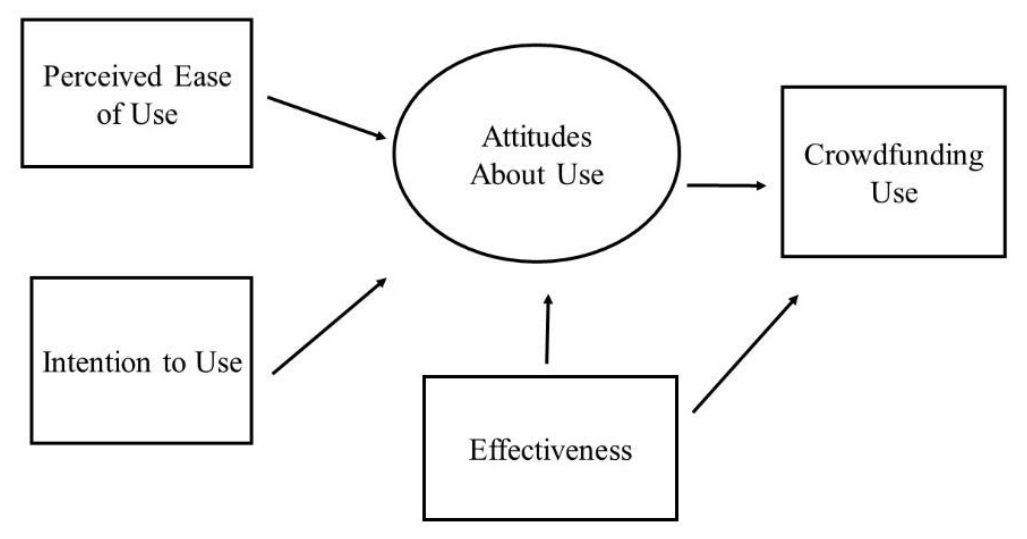

Figure 1. Crowdfunding Conceptual Model

\section{Crowdfunding Effectiveness}

The effectiveness of crowdfunding varies across campaigns and platforms. Small projects requiring less capital are easier to fund than projects requiring relatively large amounts of capital (Mollick, 2014). Further, nonprofit projects have a higher success rate than for-profit projects (Belleflamme et al., 2013). Finally, trust in borrowers and trust in crowdfunding platforms impact lenders' lending intentions, making it important for borrowers to provide high-quality information concerning loan requests and to choose crowdfunding platforms that offer outstanding services and ample security (Chen et al., 2014).

Promotion plays a critical role in crowdfunding campaign success, as publicity efforts-or lack thereof-are considered a major contributor to project failure (Hui, Gerber, et al., 2014). Web-based crowdfunding campaigns are easily shared via social networking sites, which provide a low- or no-cost opportunity to tap into a seemingly endless network of friends, family, and colleagues. Per social network theory, campaign creators can think of each social networking site user as a node connected to many other nodes via a range of relationships, including friendship and professional affiliation (Marin \& Wellman, 2010). A campaign creator sharing an investment opportunity with those in his online social network opens door for supporters to invest in the project through both financial investment and sharing the opportunity with their respective social networks. 
Promotion of crowdfunding campaigns via social media is easy and low cost; however, Hui, Gerber, et al. (2014) posited that campaign creators generally struggle to maximize the potential of social media. The reasons are that campaign creators struggle to understand network size and ability to give, effectively ask for support, and develop a reputation/fan base before launching the crowdfunding campaign (Hui, Gerber, et al., 2014). Hui, Gerber, et al. concluded that entrepreneurs can maximize utility of social media in promoting crowdfunding campaigns by measuring the size of the support network, identifying those likely to support, and identifying reputation-building opportunities.

Perceived ease of use plays an important role in the acceptance of technology (Erasmus et al., 2015). Industry growth continues as entrepreneurs opt to pursue the speedier course of lesser resistance. Whether seeking funding for a creative project or a business venture, campaign creators complete similar easy-to-navigate, straightforward tasks via crowdfunding platforms. Processes and fees for establishing a crowdfunding campaign vary by platform and campaign type; however, setting up the campaign generally includes creation of the project title and video, identification of fund use and goal, establishment of campaign duration, and identification of reward details (Hui, Greenberg, et al., 2014). In the case of investment crowdfunding, which includes both debt-based and equity-based crowdfunding campaigns-processes typically include the additional step of verifying participants' identity, income, and assets.

The nearly ubiquitous adoption of the Internet, social networking sites, and mobile computing devices undoubtedly increases the ease with which businesses may pursue and promote-and with which investors may learn about and support-crowdfunding campaigns. According to Pew Research Center, 84\% of American adults use the Internet (Perrin \& Duggan, 2015). The organization further reports $65 \%$ of adult Americans use social networking sites, with usage more likely in high-income households and among those with at least some college education (Perrin, 2015). Further, 80\% of U.S. mobile subscribers have smartphones (Nielsen, 2015).

\section{Discussion}

Barriers to entry for small startups can be a deterrent for entrepreneurship and small business. For minorities, women, and entrepreneurs from lesser developed countries, these barriers can be even more difficult to overcome. Tools such as crowdfunding may ease the barrier of access to capital. Crowdfunding is a viable alternative to traditional sources of funding such as venture capitalists and banks for small start-up companies. A shift in perceptions about crowdfunding and the effectiveness of crowdfunding will lead to an increase use of crowdfunding. The crowdfunding market is growing every year. Wierzbicka (2018) found that this market is the fastest growing market in the United States. "According to the Beauhurst report on the U.K. capital investment market in 2015 estimated at $£ 4.9$ billion, the number of transactions increased by $26 \%$ compared to the previous year," (Wierzbicka, 2018, p. 65). Share crowdfunding was the majority of these transactions and the dominant investment form for early stage development companies (Wierzbicka, 2018).

Despite this tremendous growth in the use of crowdfunding, there are still many late adopters of this technology. Understanding what factors influence the use of crowdfunding can help entrepreneurs gain access to capital through this market and ease barriers to entry. The conceptual model presented in this article is a starting point for exploring the use of crowdfunding further. Future research will include testing the validity of this model and the exploration of crowdfunding's impact on three of the other barriers-economies of scale, access to distribution, and incumbency advantages (cost disadvantages independent of scale). 


\section{References}

Bain, J. S. (1956). Barriers to new competition. Harvard University Press. https://doi.org/10.4159/harvard.9780674188037

Beaulieu, T., Sarker, S., \& Sarker, S. (2015). A conceptual framework for understanding crowdfunding. Communications of the Association for Information Systems, 37, 1. https://doi.org/10.17705/1CAIS.03701

Belleflamme, P., Lambert, T., \& Schwienbacher, A. (2013). Individual crowdfunding practices. Venture Capital, 15, 313-333. https://doi.org/10.1080/13691066.2013.785151

Bewaji, T., Yang, Q., \& Han, Y. (2015). Funding accessibility for minority entrepreneurs: An empirical analysis. Journal of Small Business and Enterprise Development, 22, 716-733. https://doi.org/10.1108/JSBED-08-2012-0099

Borello, G., De Crescenzo, V., \& Pichler, F. (2015). The funding gap and the role of financial return crowdfunding: Some evidence from European platforms. Journal of Internet Banking and Commerce, 2O, 1-20.

Boslet, M. (2015). Crowdfunding growth accelerated last year with $\$ 16.2$ bln raised. https://www.pehub.com/2015/03/crowdfunding-growth-accelerated-last-year-with-16-2-bln-raised/

Bradford, C. S. (2012). Crowdfunding and the federal securities laws. Columbia Business Law Review, 2012, $1-150$.

Bouncken, R. B., Komorek, M., \& Kraus, S. (2015). Crowdfunding: The current state of research. International Business \& Economics Research Journal, 14(3), 407-416. https://doi.org/10.19030/iber.v14i3.9206

Bruton, G., Khavul, S., Siegel, D., \& Wright, M. (2015). New financial alternatives in seeding entrepreneurship: Microfinance, crowdfunding, and peer-to-peer innovations. Entrepreneurship Theory and Practice, 39, 9-26. https://doi.org/10.1111/etap.12143

Chen, D., Lai, F., \& Lin, Z. (2014). A trust model for online peer-to-peer lending: A lender's perspective. Information Technology and Management, 15(4), 239-254. https://doi.org/10.1007/s10799-014-0187-z

Cholakova, M., \& Clarysse, B. (2015). Does the possibility to make equity investments in crowdfunding projects crowd out reward-based investments? Entrepreneurship Theory and Practice, 39, 145172. https://doi.org/10.1111/etap.12139

Colgren, D. (2014). The rise of crowdfunding: Social media, big data, cloud technologies. Strategic Finance, 96, 56-57.

Cummings, S., Daellenbach, U., Davenport, S., \& Campbell, C. (2013). Problem-sourcing: A re-framing of open innovation for R\&D organisations. Management Research Review, 36, 955974. https://doi.org/10.1108/MRR-07-2012-0177

Dahlqvist, J., Davidson, P., \& Wiklind, J. (2000). Initial conditions as predictors of new venture performance: A replication and extension of the cooper et al. study. Enterprise \& Innovation Management Studies, $1,1-17$.

Das, S., Roberts, M. J., \& Tybout, J. R. (2001). Market entry costs, producer heterogeneity, and export dynamics. National Bureau of Economic Research. https://doi.org/10.3386/w8629

Davis, F. (1986). A technology acceptance model for empirically testing new end-user information systems: theory and results (Doctoral dissertation). Sloan School of Management, Massachusetts Institute of Technology, Cambridge, MA. 
Davis, F. D. (1989). Perceived usefulness, perceived ease of use and user acceptance of information technology. Management Information Systems Quarterly, 13, 319-340. https://doi.org/10.2307/249008

Davis, F. D., Bagozzi, R. P., \& Warshaw, P. R. (1989). User acceptance of computer technology: A comparison of two theoretical models. Management Science, 35, 982-1003. https://doi.org/10.1287/mnsc.35.8.982

Disney, R., \& Gathergood, J. (2009). Housing wealth, liquidity constraints and self-employment. Labour Economics, 16(1), 79-88. https://doi.org/10.1016/j.labeco.2008.05.002

Erasmus, E., Rothmann, S., \& van Eeden, C. (2015). A structural model of technology acceptance. SA Journal of Industrial Psychology, 41, 1-12. https://doi.org/10.4102/sajip.v41i1.1222

Euchner, J. (2015). Declining barriers to innovation. Research Technology Management, 58, 1011. https://doi.org/10.5437/08956308X5806002

Fairlie, R. W., \& Krashinsky, H. A. (2012). Liquidity constraints, household wealth, and entrepreneurship revisited. The Review of Income and Wealth, 58(2), 279-306.

Gerber, E. M., \& Hui, J. (2013). Crowdfunding: Motivations and deterrents for participation. ACM Transactions on Computer-Human Interaction, 2O, 1-32. https://doi.org/10.1145/2530540

Havrylchyk, O. (2018). Regulatory framework for the loan-based crowdfunding platforms. Paris, France: Organisation for Economic Cooperation and Development. http://dx.doi.org/10.1787/24ad924a-en

Hollas, J. (2013). Is crowdfunding now a threat to traditional finance? Corporate Finance Review, 18, 27-31.

Hui, J. S., Gerber, E. M., \& Gergle, D. (2014). Understanding and leveraging social networks for crowdfunding: Opportunities and challenges. Paper presented at ACM Conference on Designing Interactive Systems, Vancouver, Canada. https://doi.org/10.1145/2598510.2598539

Hui, J. S., Greenberg, M. D., \& Gerber, E. M. (2014). Understanding the role of community in crowdfunding work. Paper presented at ACM Conference on Computer Supported Cooperative Work \& Social Computing, Baltimore, MD. https://doi.org/10.1145/2531602.2531715

Jennings, D., \& Disney, J. J. (2006). Designing the strategic planning process: Does psychological type matter? Management Decision, 44, 598-614. https://doi.org/10.1108/00251740610668860

Klapper, L., Laeven, L., \& Rajan, R. (2006). Entry regulation as a barrier to entrepreneurship. Journal of Financial Economics, 82, 591-629. https://doi.org/10.1016/j.jfineco.2005.09.006

Lofstrom, M., Bates, T., \& Parker, S. C. (2014). Why are some people more likely to become small-business owners than others: Entrepreneurship entry and industry-specific barriers. Journal of Business Venturing, 29, 232-251. https://doi.org/10.1016/j.jbusvent.2013.01.004

Lacan, C., \& Desmet, P. (2017). Does the crowdfunding platform matter? Risks of negative attitudes in twosided markets. Journal of Consumer Marketing, 34, 472-479. https://doi.org/10.1108/JCM-03$\underline{2017-2126}$

Ma, Q., \& Liu, L. (2004). The technology acceptance model: A meta-analysis of empirical findings. Journal of Organizational and End User Computing, 16, 59-72. https://doi.org/10.4018/joeuc.2004010104

Manchanda, K., \& Muralidharan, P. (2014). Crowdfunding: A new paradigm in start-up financing. Global Conference on Business and Finance Proceedings, 9, 369-374.

Marin, A., \& Wellman, B. (2010). Social network analysis: An introduction. In J. Scott \& P. J. Carrington (Eds.), The SAGE handbook of social analysis (pp. 11-25). Sage. 
Massolution. (2015, April 7). Global crowdfunding market to reach \$34.4B in 2015, predicts Massolution's 2015CF industry report: Market trends and statistics.

http://www.crowdsourcing.org/editorial/global-crowdfunding-market-to-reach-344b-in-2015predicts-massolutions-2015cf-industry-report/45376

Mollick, E. (2014). The dynamic of crowdfunding: An exploratory study. Journal of Business Venturing, 29, 1-16. https://doi.org/10.1016/j.jbusvent.2013.06.005

Naidu, S., \& Chand, A. (2017). National culture, gender inequality and women's success in micro, small and medium enterprises. Social Indicators Research, 130, 647-664. https://doi.org/10.1007/s11205-015$\underline{1203-3}$

Nielsen. (2015, December). Tops of 2015: Digital. http://www.nielsen.com/us/en/insights/news/2015/topsof-2015-digital.html

Nyuur, R. B. (2015). Unlocking the potential barriers on SMEs' uptake of scenario planning. Journal of Strategy and Management, 8, 139-154. https://doi.org/10.1108/JSMA-01-2014-0007

O’Toole, C. M., Lawless, M., \& Lambert, D. (2015). Non-bank financing in Ireland: A comparative perspective. The Economic and Social Review, 46, 133-161.

Oviatt, B. M., \& Miller, W. D. (1989). Irrelevance, intransigence, and business professors. The Academy of Management Executive, 3, 304-312.

Perrin, A. (2015). Social media usage: 2005-2015. http://www.pewinternet.org/2015/10/o8/socialnetworking-usage-2005-2015/

Perrin, A., \& Duggan, M. (2015). Americans' Internet access: 200o-2015. http://www.pewinternet.org/2015/06/26/americans-internet-access-2000-2015/

Poetz, M. K., \& Schreier, M. (2012). The value of crowdfunding: Can users really compete with professionals in generating new product ideas? Journal of Product Innovation Management, 29, 245256. https://doi.org/10.1111/j.1540-5885.2011.00893.x

Porter, M. E. (1980). Competitive strategy: Techniques for analyzing industries and competitors. Free Press.

Rossi, M. (2014). The new ways to raise capital: An exploratory study of crowdfunding. International Journal of Financial Research, 5, 8-18. https://doi.org/10.5430/ijfr.v5n2p8

Saviotti, P. P., \& Pyka, A. (2011). Generalized barriers to entry and economic development. Journal of Evolutionary Economics, 21, 29-52. https://doi.org/10.1007/s00191-010-0184-2

Sholeh, A., \& Mackey, T. (2015). Crowdfunding: A new untapped opportunity for biotechnology startups? Journal of Commercial Biotechnology, 21, 15-28.

Spulber, D. F. (2003). Entry barriers and entry strategies. Journal of Strategic Management Education, 1, $55^{-79 .}$

TABB Says SEC Rules Point to Institutionalization of Crowdfunding. (2014, April 21). Business Wire. https://www.businesswire.com/news/home/20140421005626/en/TABB-SEC-Rules-PointInstitutionalization-Crowdfunding

Talaia, M., Pisoni, A., \& Onetti, A. (2016). Factors influencing the fund raising process for innovative new ventures: An empirical study. Journal of Small Business and Enterprise Development, 23, 363378. https://doi.org/10.1108/JSBED-07-2014-0111

Thurlow, A., \& Yue, A. R. (2012). Out with the in crowd: Constructing the individual in a crowdfunding environment. Paper presented at the 42nd Atlantic School of Business Conference. http://library2.smu.ca/xmlui/handle/01/25698\#.Vz3iLb4kCM8 
Voelker, T., \& McGlashan, R. (2013). What is crowdfunding? Bringing the power of Kickstarter to your entrepreneurship research and teaching activities. Small Business Institute Journal, 9, 11-22.

Yeoh, P. (2014). Implications of online funding regulations for small businesses. Journal of Financial Regulation and Compliance, 22, 349-364. https://doi.org/10.1108/JFRC-02-2014-0012

Yousafzai, S. Y., Foxall, G. R., \& Pallister, J. G. (2010). Explaining Internet banking behavior: Theory of reasoned action, theory of planned behavior, or technology acceptance model? Journal of Applied Social Psychology, 4O, 1172-1202. https://doi.org/10.1111/j.1559-1816.2010.00615.x

Wierzbicka, K. (2018). Crowdfunding as an alternative method of raising capital. E-Finanse, 14, 5666. https://doi.org/10.2478/fiqf-2018-0027

Wroldsen, J. S. (2013). The social network and the crowdfund act: Zuckerberg, Saverin, and venture capitalists' dilution of the crowd. http://www.jetlaw.org/wpcontent/uploads/2013/03/Wroldsen.pdf 